\title{
ERGONOMI DALAM PERKANTORAN
}

\author{
Oleh: Joko Kumoro \\ jokokum@uny.ac.id
}

\section{Abstrak}

Kegiatan kantor selalu berdampingan dengan aktivitas substantif. Pekerjaan substantif terkait langsung dengan pencapaian tujuan sehingga terlibat secara intensif kepada keputusan yang bersifat strategis. Sedangkan kantor memiliki posisi sebagai pelayanan informasi agar tugas yang ditunaikan oleh aktivitas substantif dapat tercapai. Inti aktivitas perkantoran adalah pengolahan informasi. Oleh karena itu kegiatan lainnya: penghimpunan, pencatatan, penggandaan, pengiriman, dan penyimpanan informasi merupakan tugas yang bersifat melengkapi aktivitas pengolahan. Predikat kantor sebagai sumber informasi disebabkan kemampuan mengolah informasi. Pekerjaan kantor sebagian besar terkait dengan aktivitas pemakaian mata baik berupa pembacaan maupun penglihatan. Oleh karena itu perlu diciptakan suasana lingkungan yang kondusif, yaitu: menyenangkan, nyaman, dan sejuk sehingga mampu meningkatkan produktivitas. Ergonomi memberikan jawaban faktor lingkungan yang berperan dalam menentukan produktivitas kerja kantor. Cahaya, udara, suara, dan warna direkomendasikan oleh ergonomi untuk dikelola agar tercapai efisiensi kegiatan kantor.

\section{Pendahuluan}

Kehadiran kantor sebagai pendamping kegiatan substantif dewasa ini bukan merupakan pilihan tetapi menjadi keharusan. Produk kantor berupa informasi diperlukan kegiatan substantif untuk mencapai tujuan baik yang bemuansa profit maupun nirlaba.

Kegiatan kantor diwamai berbagai aktivitas berkenaan dengan pengolahan, penyediaan, dan pelayanan informasi agar pekerjaan substantif mampu membuat desisi secara tepat. Begitu pentingnya layanan informasi dalam kehidupan organisasi menempatkan kantor sebagai penyandang predikat pusat laba ketiga.

Kantor banyak terkait dengan kepentingan intem suatu organisasi sehingga efisiensi ke dalam harus menjadi perhatian utama. Efisiensi perkantoran dapat dicapai dengan meminimalisir kesalahan, meningkatkan produktivitas kerja, penyempurnaan dan penyederhanaan tata kerja, meningkatkan kecepatan dan 
akurasi ketersediaan informasi, dan sebagainya.

Efisiensi perkantoran dapat diwujudkan dengan memberikan perhatian pada kualitas dan kuantitas sumberdaya manusia, peralatan dan perlengkapan yang dipergunakan, serta lingkungan fisik tempat bekerja. Lingkungan fisik merupakan aspek yang cukup penting untuk dibicarakan karena memberi andil yang tidak kecil dalam pecapaian efisiensi perkantoran. Perbaikan lingkungan fisik merupakan pilihan yang pertu dipertimbangkan dengan mengacu pada pedoman penataan ruang yang menghendaki kepuasan dan kesehatan kerja pegawai terjamin. Persoalan ini dapat diselesaikan dengan memanfaatkan ergonomi. Ergonomi sebagai ilmu terapan mampu memberi bimbingan dalarn penyusunan lingkungan kerja yang efisien bagi kerja perkantoran.

\section{Substantif versus staf}

Kegiatan substantif atau operatif dibedakan dengan pekerjaan staf atau perkantoran karena masing-masing memiliki karakteristik yang berseberangan. Perbedaan ini pada dasamya tidak perlu dipertentangkan tetapi justru dipadukan untuk saiing melengkapi sehingga memberikan hasil yang optimal.

Kegiatan substantif ditandai oleh produk yang dihasilkan baik berupa barang maupun jasa diperuntukkan bagi pihak ekstem baik pembeli, konsumen maupun pelanggan. Sebagai konsekuensi bahwa pekerjaan substantif ini merupakan pekerjaan pokok dan menghasilkan pendapatan, revenue, income, yang pada umumnya berwujud uang. Sebaliknya, pekerjaan staf atau kantor menghasilkan suatu produk berupa informasi untuk kepertuan terutama intem organisasi, bersifat pelayanan. Oleh karena itu aktivitas kantor tidak menghasilkan pendapatan yang berwujud uang. Perbedaan kedua jenis pekerjaan tersebut tampaknya berat sebelah karena lebih menguntungkan pekerjaan substantif sehingga popularitasnya lebih tampak daripada pekerjaan staf. Secara sederana dapat diilustraskan bahwa kebanyakan orang lebih mengenal direktur jendral suatu departemen daripada sekretaris jendral. Direktur jendral merupakan simbul pengejawantahan pelaksana aktivitas substantif sementara sekretaris jendral merupakan lambang pelaksana kerja perkantoran.

Keberhasilan memadukan kedua jenis pekerjaan secara harmonis mampu menjamin kelangsungan hidup organisasi apapun bentuknya. Kegiatan substantif berkaitan erat dengan pengambilan keputusan yang bersifat strategis sehingga mampu hidup berdampingan dan jika memungkinkan menguasai para kompetitor. Keberha- 
silan memenangkan persaingan ini pada dasarnya karena tersedia informasi secara lengkap dan akurat tentang lingkungan yang dihadapi. Semua informasi dalam berbagai bentuk ini diolah dan dipersiapkan oleh aktivitas kantor.

\section{Inti aktivitas kantor}

Pekerjaan kantor dengan berbagai istilah yang dipakai secara umum diterima merupakan rangkaian kegiatan yang menghimpun, mencatat, mengolah, menggandakan, mengirim, dan menyimpan informasi yang diperlukan dalam kerja sama atau organisasi. Bermacam-macam kegiatan tersebut dapat dinilai bahwa yang menjadi inti atau panglima dalam kantor adalah pengolahan. Sedangkan kegiatan-kegiatan lainnya besifat komplementer yang diperlukan agar aktivitas pengolahan dapat dilaksanakan secara baik. Ketidakmampuan melaksanakan kegiatan pengolahan informasi sesuai dengan tuntutan lingkungan maka pada saat yang sama secara nyata kantor tidak ada. Ketidakmampuan mengolah informasi berarti nilai guna kantor menjadi pudar dan hanya menjadi beban. Sebaliknya, kecanggihan pengolahan informasi dengan didukung peralatan yang modem sudah barang tentu kantor memberikan kontribusi yang berarti dalam pencapaian tujuan. Keadaan seperti ini akan mewujudkan ide
Lynett bahwa kantor merupakan pusat laba ketiga setelah kegiatan produksi dan pemasaran (Komaruddin, 1980). Dengan kata lain bahwa perlu ada perjuangan yang tidak ringan bagi kantor agar benar-benar mampu memberikan bantuan atau pelayanan yang berarti. Tidak ada pilihan bagi kantor kecuali memperkuat kemampuan pengolahan informasi. Secara sederhana pengolahan informasi dapat dirumuskan sebagai kegiatan penyajian data atau informasi menjadi bentuk yang lebih bermanfaat.

\section{Fokus kantor}

Kantor merupakan unit yang memberikan pelayanan informasi kepada aktivitas substantif. Kegiatan substantif merupakan aktivitas organisasi yang terkait langsung dengan pencapaian tujuan. Bagian pemasaran dan bagian produksi pada suatu perusahaan, dosen pada perguruan tinggi merupakan komponen yang melaksanakan pekerjaan substantif. Pekerjaan substantif ini berhadapan langsung dengan para kompetitor masing-masing. Oleh karena itu bidang substantif berkepentingan dengan desisi atau keputusan yang bersifat strategis dalam rangka menghadapi lingkungan. Fokus utama aktivitas substantif tidak selalu efisiensi karena ditentukan oleh kondisi lingkungan atau kompetitor yang dihadapi. Organisasi yang hidup dalam lingkungan 
kacau (turbulent field) akan melakukan adaptasi agar tetap hidup bukan melakukan efisiensi kerja sehari-hari. Kegiatan adaptasi ini tidak selalu selaras dengan prinsipprinsip efisiensi bahkan hampir dapat dipastikan tidak efisien. Pada kegiatan adaptasi fokus utama adalah meraih peluang-peluang yang menuntut korban dan jika perlu merugi. Berbeda dengan lingkungan yang tenang acak (placid-randomized) cukup dihadapi dengan efisiensi aktivitas sehari-hari. Ilustrasi tersebut menggambarkan betapa pentingnya keputusan aktivitas substantif harus menyelaraskan dengan keadaan lingkungan agar dapat tetap hidup.

Berbeda dengan aktivitas perkantoran yang harus memfo-kuskan efisiensi intem agar dapat memberikan pelayanan terhadap pekerjaan substantif secara berarti. Banyak faktor yang memiliki pengaruh terhadap efisiensi kerja kantor, meliputi: (1) suasana tempat kerja, (2) lingkungan tempat kerja, (3) corak hasil kerja, (4) proses atau prosedur, (5) perlengkapan dan fasilitas, (6) alat, (7) tata ruang kerja, (8) gerak tangan dan tubuh, (9) manusianya itu sendiri yang harus memiliki keinginan, kemampuan dan kemahiran kerja. Dengan memperhatikan faktor-faktor tersebut maka efisiensi kantor dapat diciptakan dengan mengelola lingkungan fisik yang selaras dengan tuntutan kerja.
Pada umumnya telah disepakati bahwa tata ruang kerja kantor yang efisien hans mengacu empat asas dan tujuh pedoman. Salah satu pedoman tata ruang kantor yang relevan untuk diperhatikan adalah terjaminnya kesehatan dan kepuasan kerja pegawai. Untuk merealisasikan pedoman tersebut banyak aktivitas yang dapat dilakukan antara lain memberi perhatian terhadap lingkungan fisik yang memiliki pengaruh secara psikis maupun fisik.

\section{Ergonomi dalam kantor}

Berdasarkan kesadaran bahwa faktor lingkungan fisik memberikan sumbangan yang cukup berarti terhadap efisiensi perkantoran maka diperlukan suatu petunjuk yang mampu melakukan identifikasi. Ergonomi merupakan pilihan untuk memberikan jawaban dalam menyusun lingkungan kerja yang kondusif. Ergonomic, the study of relationship of employees to their physical environment, is helpful in designing an effective environment (Quible, 1984: 122). Ide yang selaras juga disampaikan oleh Kallaus dan Keeling yang menyatakan bahwa ergonomic is the science that explains the relationship of workers to the physiological and psychological factor in their environment (1987:403-404). Pada dasamya ergonomi merupakan ilmu yang membahas pengaruh lingkung- 
an fisik terhadap psikis dan fisiologis karyawan. Secara psikis karyawan harus dijaga selalu merasa senang, puas, aman, dan sebagainya. Demikian pula fisik karyawan harus dijaga agar selalu sehat, segar , tidak cidera sehingga mampu memberikan karya yang terbaik.

Produktivitas dan kualitas kerja kantor sangat dipengaruhi oleh keadaan lingkungan fisik. Aktivitas kantor terutama terkait dengan pengolahan informasi sebagian besar melibatkan pemakaian mata secara luas dalam bentuk membaca dan melihat. Bahkan secara tegas Suma'mur (1988) menyatakan bahwa ergonomi itu dimaksudkan untuk mencapai produktivitas dan efisiensi setinggi-tingginya melalui pemanfaatan faktor manusia seoptimaloptimalnya. Lingkungan fisik yang tidak kondusif akan menimbulkan penurunan produktivitas, moral pegawai rendah, mangkir atau absensi, dan tingkat kesalahan tinggi.

Banyak komponen dibicarakan oleh ergonomi dalam mendisain lingkungan kerja yang kondusif bagi kerja perkantoran, yaitu: (1) cahaya , (2) udara, (3) wama, dan (4) suara. Cahaya sangat penting bagi pekerjaan kantor mengingat aktivitas di dalamnya banyak mempergunakan pikiran dan mata yang luas. Cahaya yang baik harus dapat disiapkan agar menghasilkan informasi yang memenuhi syarat. Cahaya yang baik memenuhi kebutuhan tuntutan pekejaan baik secara kualitatif maupun kuantitatif. Kedua aspek cahaya ini dapat dipenuhi dalam waktu bersamaan walaupun memakan biaya yang cukup besar. Kuantitas cahaya menunjukkan besarnya kebutuhan penyinaran untuk tiap-tiap jenis pekerjaan yang diukur dengan satuan footcandle. Sebagai ilustrasi perlu dikemukakan bahwa footcandie merupakan banyaknya cahaya yang dipancarkan dari sebuah lilin ukuran biasa pada sebuah benda yang jaraknya satu kaki dari lilin itu atau kurang lebih 30,48 centimeter (The Liang Gie, 1998). Berkaitan dengan kuantitas cahaya, pekerjaan kantor diklasifikasikan menjadi empat macam, yaitu pekerjaan yang memerlukan penglihatan: (1) sederhana, (2) sepintas lalu, (3) biasa, dan (4) tajam. Sudah barang tentu mudah dipahami bahwa pekerjaan dengan penglihatan sederhana memerlukan kuantitas cahaya yang paling sedikit. Sebaliknya, pekerjaan dengan penglihatan tajam memeriukan kuantitas cahaya yang terbesar. Untuk memperjelas keterkaitan antara jenis pekerjaan kantor dan kebutuhan cahaya dapat diperha-tikan tabel berikut : 
Tabel 1.

Klasifikasi Pekerjaan Kantor \& Kebutuhan Jumlah Cahaya

\begin{tabular}{|l|l|c|}
\hline No & Jenis Aktivitas Kantor & Footcandle \\
\hline 1. & Pekerjaan Dengan Penglihatan Sederhana & $10-20$ \\
\hline 2. & Pekerjaan Dengan Penglihatan Sepintas Lalu & $20-30$ \\
\hline 3. & Pekejaan Dengan Penglihatan Biasa & $50-100$ \\
\hline 4. & Pekerjaan Dengan Penglihatan Tajam & $100-200$ \\
\hline
\end{tabular}

Sumber: The Liang Gie, 1998

Aspek lain yang penting dari penyinaran untuk melaksanakan aktivitas kantor adalah mutu cahaya. Cahaya yang memiliki mutu terbaik adalah tidak menimbulkan bayangan dan besifat uniform. Ada beberapa jenis cahaya mulai dari yang bermutu tidak baik sampai cahaya yang terbaik, sebagai berikut: (1) cahaya langsung, (2) cahaya setengah langsung, (3) cahaya setengah tidak langsung, dan (4) cahaya langsung . Pembedaan antara satu cahaya dengan dengan jenis cahaya lainnya ditandai dengan banyak sedikitnya sinar memancar dari sumbernya jatuh ke meja pegawai. Semakin banyak sinar yang memancar dari sumbernya cenderung cahaya langsung, sebaliknya semakin besar sinar jatuh ke meja karyawan berasal dari pantulan langit-langit dan dinding bagian atas maka cahaya tersebut cenderung bersifat tidak langsung. Sudah barang tentu cahaya yang terbaik adalah yang memenuhi kuantitas sesuai jenis pekerjaan dan secara kualitas merupakan cahaya tidak langsung. Cahaya yang baik memiliki beberapa keuntungan, yaitu: (1) meningkatkan produktivitas meskipun sukar diukur; (2) kualitas kerja semakin baik; (3) kelelahan mental dan syaraf mata dapat dikurangi; (4) moral pegawai meningkat; prestise organisasi lebih tinggi.

Udara merupakan faktor yang cukup penting untuk dikelola agar karyawan mampu bekerja secara efisien. Ada beberapa aspek udara yang pertu mendapat perhatian yaitu: (1) temperatur atau suhu ; (2) kelembaban; (3) sirkulasi, dan (4) kebersihan.

Karyawan merasa betah bekerja apabila udara di sekeliting nya berada di bawah suhu badan yang pada umumnya sekitar 37 derajad celcius. Tuntutan ini harus dipenuhi agar karyawan mampu mengeluarkan panas yang ada dalam tubuhnya. Pada dasamya tidak ada titik suhu tertentu yang nyaman untuk bekerja bagi semua orang. Kebutuhan suhu yang nyaman untuk bekerja akan dipengaruhi oleh jenis kelamin, usia, dan ukuran badan. 
Namun demikian secara umum karyawan akan merasa nyaman bekerja dengan suhu sekitas 25,7 derajad celcius. Oleh karena itu perlu adanya manipulasi terhadap suhu tempat kerja sehingga mendekati tuntutan kerja masing-masing karyawan. Manipulasi udara tempat kerja dapat dilakukan dengan mempertimbangkan perbedaan terhadap udara di luar ruang maksimum 4 deraiad celcius. Aspek kelembaban udara juga perlu diatur agar kesehatan maupun kepuasan karyawan dapat terjamin. Kelembaban merupakan kandungan uap air pada udara yang dinyatakan dalam persentase. Bagi karyawan untuk bekerja secara nyaman harus dapat mengeluarkan peluh dari dalam tubuhnya. Tubuh dapat mengeluarkan peluh menuntut persyaratan bahwa udara di sekeliling cukup kering sehingga mampu menerima uap air baru. Kelembaban udara yang nyaman untuk bekerja bagi sebaian besar karyawan sebesar 40 - 60 persen. Sebagai kelengkapan pernahaman, disajikan kondisi ke- lembaban udara di Indonesia, seperti tertuang pada tabel 2.

Data di atas memberi gambaran bahwa di Indonssia temyata udara terlalu lembab, jauh dari tuntutan persyaratan kerja efisien. Jakarta untuk mewakili daerah dataran rendah sedangkan Jawa Barat merupakan wakil dataran tinggi. Secara tegas American Society of Heating and Ventilating Engineering (ASHVE) menetapkan kondisi udara yang nyaman untuk bekerja adalah suhu 25,6 derajad celcius dan nilai kelembaban $45 \%$. Ada dua aspek penting lainya dari udara yang pertu memperoleh perhatian yaitu sirkulasi dan kebersihan. Kebutuhan sirkulasi udara tergantung dari : (1) luas ruangan, (2) jumlah orang yang bekerja dalam ruangan; (3) besar kecilnya jendela, dan (4) ukuran langit-langit. Sirkulasi ini dapat diatur secara leluasa oleh organisasi yang bersangkutan, sedangkan kebersihan tidak selamanya seperti itu. Kebersihan udara apabila telah menyangkut wilayah yang luas dan bersifat makro maka

Tabel. 2

Kelembaban Udara di Indonesia

\begin{tabular}{|l|c|c|c|c|}
\hline \multirow{2}{*}{ Daerah } & \multicolumn{4}{|c|}{ Bulan } \\
\cline { 2 - 5 } & Jan-Mar & Apr-Jun & Jul-Sep & Okt - Des \\
\hline Jakarta & $79,58 \%$ & $77,33 \%$ & $75,08 \%$ & $76,92 \%$ \\
\hline Jawa Barat & $85,13 \%$ & $85,23 \%$ & $81,33 \%$ & $85,10 \%$ \\
\hline
\end{tabular}


organisasi secara intern tidak mampu menyelesaikan. Kasus seperti ini menghendaki campur tangan pemerintah karens sudah menyangkut barang publik (public goods). Secara sederhana pengelo-laan udara untuk memanipulasi suhu, kelembaban, sirkulasi, dan kebersihan dalam batas tertentu dapat dipergunakan $A C$, lubang ventilasi, dan kipas angin.

\section{Wama merupakan aspek}

yang memiliki pengaruh terutama pada psikis atau kejiwaan pegawai. Pe-milinan wama yang cocok dengan tuntutan pekerjaan akan memiliki pengaruh yaitu karyawan bekerja dengan senang hati, bergairah, merasa tidak tertekan, dan ungkapan jiwa lainnya yang mendukung Pengaturan dimaksudkan efektivitas terhadap untuk: warna menimbulkan kegairahan dan kenikmatan dalam bekerja, dan (2) menunjukkan aspek estetika atau keindahan. Warna memiliki da-ya pantul yaitu kemampuan untuk memantulkan kembali cahaya yang diterima dinyatakan dalam persentase. Oleh karena itu semakin banyak cahaya yang dipantulkan mengandung arti semakin terang ruangan. Semakin muda atau terang warna memiliki daya pantul yang tinggi. Pada dasarnya jenis warna yang bermacam-macarn dan jumlahnya hampir tak terbatas ini dibentuk oleh kombinasi tiga warna primer, yaitu: merah, kuning, dan biru. Setiap warna memiliki dampak psikologis yang berbeda-beda, seperti terlihat pada tabel 3.

Tabel. 3

Wama dan Pengaruhnya

\begin{tabular}{|l|l|l|l|}
\hline Warna & \multicolumn{1}{|c|}{ Sifat } & \multicolumn{1}{c|}{ Pengaruh } & \multicolumn{1}{c|}{ Untuk Ruang } \\
\hline Merah & $\begin{array}{l}\text { Dinamis, } \\
\text { merangsang }\end{array}$ & $\begin{array}{l}\text { Menimbuikan } \\
\text { semangat }\end{array}$ & $\begin{array}{l}\text { Pekerjaan sepintas } \\
\text { atau singkat }\end{array}$ \\
\hline Kuning & $\begin{array}{l}\text { Keanggunan, } \\
\text { bebas }\end{array}$ & $\begin{array}{l}\text { Menimbulkan } \\
\text { perasaan gembira dan } \\
\text { merangsang urat } \\
\text { syaraf }\end{array}$ & $\begin{array}{l}\text { Gang-gang, } \\
\text { jalan (lorong) }\end{array}$ \\
\hline Biru & $\begin{array}{l}\text { Tenang, } \\
\text { tentram, } \\
\text { Sejuk }\end{array}$ & $\begin{array}{l}\text { Mengurangi } \\
\text { ketekanan/ } \\
\text { ketegangan }\end{array}$ & Berpikir konsentrasi \\
\hline
\end{tabular}


Sebagai pedoman dalam pemilihan warna dapat disarankan sebagai berikut: (1) pemakaian warna selalu dikaitkan dengan faktor lain yang berada dalam ruangan; (2) pemakaian dua wama yang kontras akan mempercepat kelelahan mata; (3) warna yang muda atau cerah membuat ruang kecil tampak besar, ruang rendah berkesan tinggi; (4) Pemilihan warna langit-langit lebih muda daripada wama dinding. semakin ke bawah dipilih warna yang tua.

Suara merupakan aspek ergonomi yang cukup penting mempengaruhi aktivitas perkantoran. Suara yang perlu dikendalikan adalah yang bersifat tidak menyenangkan yang disebut juga kebisingan. Kebisingan dapat bersumber dari ekstern seperti deru kendaraan di jalan, suara sirine dan sebagainya. Sumber intern juga berpotensi untuk meghasilkan kebisingan seperti: suara mesin-mesin kantor, percakapan, perlatan, dan langkah para pegawai. Kebisingan dapat diukur dengan decible (desibel), yaitu tingkatan paling kecil dari suara yang dapat ditangkap oleh pendengaran manusia dinyatakan satu desibel. Berdasarkan ukuran desibel tersebut suatu tempat dapat dikelompokkan menjadi beberapa jenis, sebagaimana tabel 4 .

Kebisingan sangat merugikan kesehatan para pegawai antara lain: (1) kerusakan indera pendengar, (2) kelelahan yang bertambah dan semangat kerja cepat turun, (3) efek psikologis berupa cepat marah dan perasaan terganggu, (4) salah menagkap ide, dan sebagainya. Aktivitas kantor yang paling banyak dipengaruhi oleh kebisingan terutama kegiatan pemakaian fikiran, pekerjaan yang bersifat konsentrasi terus-menerus, membuat keputusan, mengetik, pembukuan, dan sejenisnya. Mengingat dampak yang cukup luas bagi efisiensi kerja kantor maka pengendalian kebi-singan perlu dilakukan sebaik-baik-nya

Tabel. 4

Tingkat Kebisingan Ruang

\begin{tabular}{|c|l|}
\hline Decible & \multicolumn{1}{|c|}{ Office Area } \\
\hline 90 & Loud office machines room \\
\hline 70 & Noisy office \\
\hline 50 & Average office \\
\hline 30 & Quiet office \\
\hline 10 & Sound proof office \\
\hline
\end{tabular}

Sumber: Quible, 1984: 132 
desain gedung bebas dari kebisingan atau proper construc-tion; (2) mempergunakan lapisan penyerap suara pada dinding, langitlangit, dan alat-alat yang mengeluarkan suara atau sound-absorbing materials, (3) pemakaian alat-alat penyerap suara atau sound-absorbing devices, dan (4) mempergunakan penymbat telinga atau masking.

Dewasa ini untuk meningkatkan gairah kerja kantor sering diperdengarkan musik tertentu. Musik adalah sebuah suara yang bersifat menyenangkan sehingga dapat dipergunakan secara terbatas. Bagi pekerjaan yang memiliki resiko besar tidak cocok dipergunakan musik. Telah diakui secara umum bahwa musik yang cocok akan memiliki pengaruh: (1) membangkitkan motivasi dan gairah dalam menjalankan aktivitas, (2) menimbulkan perasaan senang, (3) menghilangkan perasaan tertekan. Ada beberapa pertimbangan pemanfaatan musik, yaitu: harus dapat. menciptakan suasana yang nyaman dalam bekerja sehingga menguntungkan fikiran, (2) musik bernilai bagi pekerjaan yang mempergunakan tangan atau jabatan yang sedikit membutuhkan kegiatan mental; (3) musik tidak memiliki arti apabila latar belakang bising; irama tidak terlalu lambat ataupun cepat. Berkaitan dengan hal tersebut maka pemakaian musik harus dipertimbangkan mengenai: jenis, saat, lama, frekuensi, dan sifat pekerjaan. Menurut Suma'mur (1989) musik yang cocok untuk kegiatan kantor adalah: (1) tempo sedang dan disesuaikan dengan keadaan; tidak terlalu cepat dan tidak terialu lambat, (3) jenis musik instrumentalia.

\section{Penutup}

Aktivitas kantor yang utama berupa pengolahan informasi untuk memberikan palayanan kepada pekerjaan substantif. Pelaksanaan kegiatan tersebut menuntut prasya-rat tersedianya lingkungan fisik yang kondusif bagi berlangsungnya pekerjaan. Mengingat aktivitas kantor didominasi dengan kegiatan membaca dan penglihatan yang luas maka diperlukan pengelolaan unsurunsur: cahaya, suhu, wama, dan suara.

Ergonomi merupakan suatu ilmu yang membahas pengaruh fisik-fisiologis dan psikis manusia terhadap lingkungan fisik. Tawaran yang ada dari ergonomi ini perlu disambut dan dimanfaatkan secara bijaksana dalam menciptakan lingkungan kerja kantor yang merangsang peningkatan produktivitas kerja.

\section{Daftar Pustaka}

Kallaus, Norman F. dan B. Lewis Keeling. 1987. Administrative Office Management, Ohio: 
South-Western Publishing

Company.

Komaruddin. 1981. Menejemen

Kantor, Teori dan Praktik,

Bandung: Sinar Baru.

Lubis, Hari dan Martani Huseini. 1987. Teori Organisasi, Suatu Pendekatan Makro, Jakarta: PAU IImu-IImu Sosial Universitas Indonesia.

Quible, Zane K. 1984. Administrative Office Management, an Introduction, third edition, Virginia: Reston Publishing Company Inc.

Sugandha, Dann. 1986. Menejemen Administrasi, Suatu Pendekatan Sistem Dalam Menejemen Perkantoran, Bandung: Sinar Baru.

\section{Biodata Penulis}

Drs. Joko Kumoro, M.Si. dosen matakuliah Menejemen Perkantoran dan Perpajakan, staf pengajar Pend. Adm. Perkantoran/PDU FIS UNY sejak tahun 1985. Lahir di Purworejo, 26 Juni 1960, S2 Jurusan IImu Administrasi ISIP Universitas Indonesia, Jakarta, lulus tahun 1997. 